
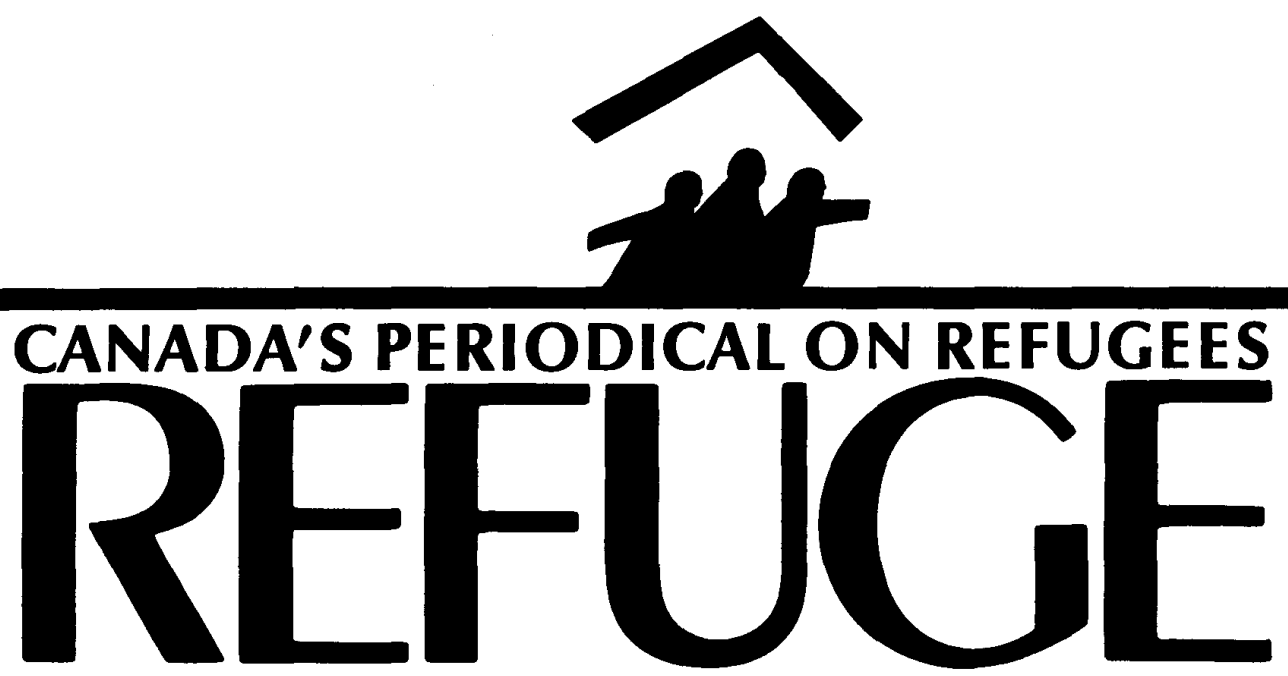

Vol. 5 No. 1

October 1985

\title{
VIVA FLORA! VIVA FLORA!
}

MONTREAL, September 28, 1985 Three hundred demonstrators - men and women, adults and children, Latin Americans and Bangladeshis - parade with placards outside a huge Roman Catholic cathedral in the heart of downtown Montreal. Holding signs reading "We want permanent residence," "Canada promised freedom," or protesting tyranny and torture in their homelands, the demonstrators chant their pleas and protests.

Inside the salle de la cathédrale, Employment and Immigration Minister Flora MacDonald discusses the Plaut Report with representatives of the Standing Conference of Organizations Concerned with Refugees.

Following the Minister's opening address, a panel of delegates focus on the issues of most concern to them in Rabbi Plaut's recommendations on the process of refugee determination in Canada: separating refugee from immigration issues; universal access to the determination system; the right to counsel; nonadversarial hearings; and the myriad of details on the structure of the system for determining refugee status. How many people should sit on the initial panel? What is their status? How should they be trained? Who should hear any appeal? On what grounds?

How many times in the last five years have the delegates discussed these issues? How many thousands, nay, tens, hundreds of thousands of hours have already been spent discussing them by lawyers, church representatives, academics, government officials, and refugee delegations? How many times has the Minister listened to these same debates?

But perhaps this time was different. The Plaut Report was on the Minister's desk recommending specific changes to the system. Bill C- 55 had been tabled in the House of Commons that week to expand the Immigration Appeal Board from 18 to 50 members; a belated response to the huge backlog of cases and the crisis to the whole system wrought by the Supreme Court decision in the Singh case that the absence of an oral hearing for a refugee claimant was a denial of a fundamental right.

The Minister listens patiently. She takes copious notes. When a delegate argues that the hearing officer be required to have legal training, she intervenes to ask whether this means officers had to be lawyers, and receives reassurance that this is not the intent.

At the coffee break, the Minister goes

outside to speak to the demonstrators individually at first and then as a group. The morning's shouts turn to cheers when she finishes. VIVA FLORA! VIVA FLORA! The children form an honour guard, applauding as she returns to the hall.

After all this time, after all the delays, after all the anxiety among those who wait in limbo for months and years for their status to be determined, one would expect the Minister to be the target of anger and fury. One presenter expresses impatience, another is righteous, insistent and demanding. But the overwhelming tone is advisory and supportive. And this meeting is not in Toronto. It is in the heartland of the firebrands of Montreal.

Bill C- 55 had just been tabled in a form that seemed to ignore all the representations on the draft bill the participants had made over the summer. Did the bill not appear to undercut their fundamental conviction that immigration and refugee

continued on $p .2$

\section{IN THIS ISSUE:}

The Plaut Report by Howard Adelman

page 3

Beyond the Plaut Report by Charles Smith

page 6

Compassion and Pragmatism by James Hathaway

page 9

A New Inland Refugee Determination Procedure by Michael Schelew 


\section{Viva Flora (continued from p.1)}

issues must be separated entirely? Yet Flora is greeted not simply with courtesy, but with warmth. When her advisers plan to lunch at an outside restaurant to get away from the pressure-cooker atmosphere of the conference, she insists on joining the delegates for their church basement chicken.

One feels the warmth and the hope were direct responses to her sincere convictions and concern. When a delegate from SOS Guatemala describes her personal experience as a refugee coming to Canada and feeling that the interrogation of the immigration officer was just what she had fled in Latin America, Flora's face clearly responds to the distress and terror in the refugee's tale.

Now is the time for sentiment and sympathy to be translated into words and actions.

H.A.

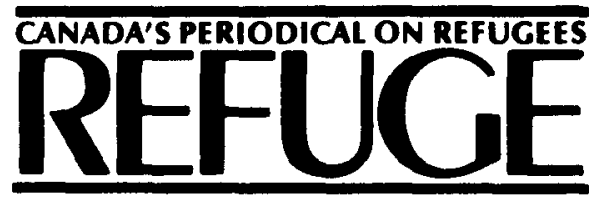

Canada's Periodical on Refugees c/o Refugee Documentation Project, York University, 4700 Keele Street, North York, Ontario M3J 1P3

Editor:

Howard Adelman

Managing Editor:

Leslie Rider

Typesetting and Layout:

Publications Department, York University

Refuge is dedicated to encouraging assistance to refugees, by providing a forum for sharing information and opinion on Canadian and international issues pertaining to refugees. It is published four times a year by the Refugee Documentation Project. It is a non-profit, independent periodical supported by private donations and by subscriptions. It is a forum for discussion, and the views expressed do not necessarily reflect those of its funders or staff.

All material in Refuge may be reproduced without permission unless copyrighted or otherwise indicated. Credit should be given to the author or source if named.

Subscription rates for one year are $\$ 20.00$. Please enclose payment with your order. No discounts can be given for American funds because of bank charges for foreign cheques.

Logo design:

Dreadnaught Cooperative Inc., Toronto

Second Class Mail Registration No. 5512 ISSN 0229-5113

\section{Resolution of the Standing Conference of Canadian Organizations Concerned for Refugees}

\author{
(Spring Consultation, May 30, 1985)
}

\section{RESOLUTION: REGARDING PROCEDURES TO HANDLE THE REFUGEE CLAIMS BACKLOG CREATED AS A RESULT OF THE APRIL 4, 1985 SUPREME COURT DECISION}

WHEREAS, the Supreme Court of Canada has ruled that the refugee determination process in Canada does not meet the requirements of the Canadian Charter of Rights and Freedoms,

AND,

WHEREAS, effective April 4, 1985 all claimants in the process are entitled to a process that does meet the requirements,

AND,

WHEREAS, the estimated 20,000 persons in the process now represent a backlog of major logistical proportions since it could take up to 10 years to handle these cases under existing resource constraints,

BE IT RESOLVED, that the Spring Convocation of the Standing Conference of Canadian Organizations Concerned for Refugees recommend that a universal program of special measures be adopted by the government to speedily facilitate a humanitarian solution to all persons in the refugee determination process on April 4, 1985. The special measures should apply equally to all people caught by our faulty process regardless of nationality or ethnic origin. It would be unjust to ask people, many of whom have been in our old and inadequate process for several years, to return to the beginning to start over.

BE IT ALSO RESOLVED, that the special measures taken to handle the backlog be done without any modifications to the Immigration Act.

\section{Letters to the Editor:}

\section{Dear Editor:}

I am writing to you in regard to the article by David Matas entitled "The Plight of Refugee Claimants" which was in the May, 1985 issue of your magazine volume 4 , number 4 .

In that article Mr. Matas commented on the Legal Aid Plan in Ontario and stated that except in rare circumstances refugee claimants are not issued legal aid certificates. Unfortunately, he did not address the issue of the community legal clinic which is able to supply legal assistance to refugee claimants on a without cost basis.

There are over 45 community legal clinics throughout the Province of Ontario at last count and many of those clinics supply legal services in the area of immigration.

I agree with Mr. Matas when he speaks of a claimant without a lawyer being at a serious disadvantage. While lawyers in community legal clinics can help in some cases with refugee claims, the workloads necessitate that not all refugee claimants are able to utilize their services. There is a need to have a system financed through the Ontario Legal Aid Plan whereby Duty Counsel is available at the port of entry to assist refugees in the initial processing of their claims. Such a plan would require cooperation between the federal and provincial levels of government in order for it to be successful.

It was an excellent idea to have a special issue dealing with the problems of Sri Lanka. I hope that you will follow such a format in future issues of your magazine.

Yours very truly,

\section{FLEMINGDON COMMUNITY \\ LEGAL SERVICES \\ Marjorie Hiley \\ Director}

